University of Nebraska - Lincoln

DigitalCommons@University of Nebraska - Lincoln

Faculty Publications, Department of History

History, Department of

Winter 1991

\title{
Weimar Culture and the Rise of National Socialism: The Kampfbund für deutsche Kultur
}

Alan E. Steinweis

University of Nebraska - Lincoln, asteinweis1@unl.edu

Follow this and additional works at: https://digitalcommons.unl.edu/historyfacpub

Part of the History Commons

Steinweis, Alan E., "Weimar Culture and the Rise of National Socialism: The Kampfbund für deutsche Kultur" (1991). Faculty Publications, Department of History. 79.

https://digitalcommons.unl.edu/historyfacpub/79

This Article is brought to you for free and open access by the History, Department of at DigitalCommons@University of Nebraska - Lincoln. It has been accepted for inclusion in Faculty Publications, Department of History by an authorized administrator of DigitalCommons@University of Nebraska - Lincoln. 


\title{
Weimar Culture and the Rise of National Socialism: The Kampfbund für deutsche Kultur
}

\author{
Alan E. Steinweis
}

B ETWEEN 1928 and 1932, the National Socialist movement transformed itself from an insurgent fringe party into Germany's most potent political force. The most important factor in this dramatic turnabout in political fortunes was the rapid deterioration of the German economy beginning in 1929. It does not, however, logically follow that the German people simply fell into the lap of the party and its charismatic leader. To the contrary, the party aggressively employed sophisticated propagandistic and organizational strategies for attracting and mobilizing diverse segments of German society. With the onset of the economic crisis, and the consequent social and political turmoil, the party stood ready to receive, organize, and mobilize Germans from all social strata. ${ }^{1}$

Cultural issues featured prominently in propaganda, particularly in the latter, decisive phase of the Nazis' rise to power. After its breakthrough in the September 1930 Reichstag elections, the NSDAP wasted little time before going on a cultural offensive. In December 1930, for example, provocations in Berlin achieved a major symbolic victory, compelling the government to ban the film version of Remarque's All Quiet on the Western Front. ${ }^{2}$ Despite such successes, the movement's reliance on artis-

For their comments on earlier drafts of this paper, the author would like to thank Geoffrey Giles, Wolfgang Natter, William S. Allen, and the participants in the facultygraduate student colloquium of the Department of History, Florida State University.

1. For background on the mobilization of various German constituencies, I have relied on the following works: Michael H. Kater, The Nazi Party: A Social Profile of Members and Leaders, 1919-1945 (Cambridge, MA, 1983); Thomas Childers, The Nazi Voter: The Social Foundations of Fascism in Germany, 1919-1933 (Chapel Hill, 1983); Detlef Mühlberger, Hitler's Followers: Studies in the Sociology of the Movement (London, 1991); and Jürgen W. Falter, Hitlers Wähler (Munich, 1991). An insightful treatment of the importance of propaganda to mobilization strategies is Ian Kershaw, "Ideology, Propaganda, and the Rise of the Party," in Peter D. Stachura, ed., The Machtergreifung (London, 1983), 162-81.

2. For a discussion of this episode in the context of political strategy, see Martin Broszat, Hitler and the Collapse of Weimar Germany, trans. V. R. Berghahn (Leamington Spa, 1984), 32-36. 
tic and cultural strategies during its rise to power has not been subjected to rigorous analysis. Although several studies have examined the cultural policies implemented by the Nazis once in power, the historiography is deficient when it comes to the role of cultural politics in pre-1933 mobilization strategies. Ironically, the use of art and culture as a political weapon by the left-wing parties has generated far more scholarly interest. $^{3}$

At the time of the seizure of power, the Kampfbund für deutsche Kultur functioned as the movement's primary vehicle for cultural and artistic mobilization. Yet little is known about this organization. Although the Kampfbund forms the focus of a chapter in Reinhard Bollmus's authoritative study of Alfred Rosenberg's career in the movement, Bollmus concentrates primarily on the role of the Kampfbund in the Byzantine jurisdictional conflicts of the Third Reich. ${ }^{4}$ In contrast, Bollmus says relatively little about the Kampfbund's contribution to the growth and popularity of the movement before 1933 . Several recent turns in the historiography of the Weimar Republic and pre-1933 National Socialism would now make a fresh look at the Kampfbund particularly worthwhile. There has been a renewal of interest in the importance of broad cultural, as opposed to strictly socioeconomic, factors in the weakening of Weimar democracy and the success of Nazism. ${ }^{5}$ Also increasingly prevalent have been studies investigating the social, rather than the purely political, mechanisms through which the völkische worldview was disseminated among the German population. ${ }^{6}$ The Kampfbund constitutes

3. For a recent example see W. L. Guttsman, Workers' Culture in Weimar Germany: Between Tradition and Commitment (New York, 1990).

4. Reinhard Bollmus, Das Amt Rosenberg und seine Gegner: Studien zum Machtkampf im nationalsozialistischen Herrschaftssystem (Stuttgart, 1970), 27-54. An earlier study still valuable for its detailed treatment of organizational and financial questions is Herbert P. Rothfeder, "A Study of Alfred Rosenberg's Organization for National Socialist Ideology" (Ph.D. diss., University of Michigan, 1963), 29-54. The classic study by Hildegard Brenner, Die Kunstpolitik des Nationalsozialismus (Reinbek, 1963) is useful for context, but on issues related to the Kampfbund has been supplanted by Bollmus. Particularly insightful on the Kampfbund's activities in the sphere of architecture is Barbara Miller Lane, Architecture and Politics in Germany, 1918-1945 (Cambridge, MA, 1968), 148-60. Fred K. Prieberg, Musik im NS-Staat (Frankfurt, 1982), 36-40, provides a useful sketch of Kampfbund activities in the music field.

5. See Modris Eksteins, The Rites of Spring: The Great War and the Birth of the Modern Age (Boston, 1989); Detlev, J. K. Peukert, "The Weimar Republic-Old and new Perspectives," German History 6 (1988): 133- $\rightarrow$ Thomas Childers, "The Social Language of Politics in Germany: The Sociology of Political Discourse in the Weimar Republic," American Historical Review 95 (April 1990): 331-58; Larry Eugene Jones, "Culture and Politics in the Weimar Republic," in Gordon Martel, ed., Modern Germany Reconsidered (London, 1991).

6. Rudy Koshar, Social Life, Local Politics, and Nazism: Marburg 1880-1935 (Chapel Hill, 1986); Peter Fritzsche, Rehearsals for Fascism: Populism and Political Mobilization in Weimar Germany (New York, 1990). 
an excellent case study of how artistic and cultural activism shaped the Nazi movement's public image during the later stages of the "time of struggle," helping to pave the party's path to social respectability among the propertied and educated middle class (Besitz und Bildungsbürgertum).

The origins of the Kampfbund must be understood in two broader contexts: that of the cultural politics of the Weimar Republic, and that of the mobilization strategies employed by the National Socialist movement. ${ }^{7}$ Conflict between tradition and experimentation on the artistic scene reflected the profound social and ideological cleavages of Weimar Germany. The efflorescence of artistic modernism after World War I had coincided with a profound shake-up of the social relationships and economic structures that had prevailed before the war. Thus, to many Germans, artistic modernism exacerbated a more fundamental disorientation. Believing the proper function of art to be a lifting of the spirit through an emphasis on beauty and heroism, the critics of modernism condemned forms of art conceived as means for exploring new perspectives on reality and for bringing society's blemishes into sharper focus. They believed that Germany had lost its traditional bearings, and that the new art functioned as a critical and corrosive force, promoting the unraveling of the social fabric by questioning the legitimacy of prevailing attitudes and institutions. Cultural anxiety manifested itself in many forms and across a wide political spectrum. ${ }^{8}$ On the extreme Right, it often assumed the form of conspiracy theory: the threat to traditional German culture was said to emanate from a network of racially, spiritually, and even financially interconnected artistic and cultural movements, led by Jews and Marxists, promoted by feminists, and most conspicuously symbolized by the increasing visibility of "Negroes" on the art scene.

Among Germans professionally involved in the arts, modernism could represent more than an affront to prevailing sensibilities. It could also pose a personal threat to artists who understood themselves to be the guardians of tradition, a role in which many took a good deal of pride, and for which several received handsome financial compensation. Para-

7. Surveys on artistic and cultural trends in Weimar Germany include Peter Gay, Weimar Culture: The Outsider as Insider (New York, 1968); Walter Laqueur, Weimar: A Cultural History (New York, 1974); Jost Hermand and Frank Trommler, Die Kultur der Weimarer Republik (Munich, 1978). Gary Stark, Entrepreneurs of Ideology: Neoconservative Publishers in Weimar Germany (Chapel Hill, 1981) also contains much useful material on cultural issues.

8. I have attempted elsewhere to compare and contrast the Nazi artistic and cultural critique with those of other parties of the Weimar Right. See Alan E. Steinweis, "Conservatism, National Socialism, and the Cultural Crisis of the Weimar Republic," in Larry Eugene Jones and James Retallack, eds., Between Reform, Reaction and Resistance: Studies in the History of German Conservatism from 1789 to 1945 (New York, 1992). 
doxically, the financially unsuccessful could conveniently blame their professional misfortunes on the new trends. The new art, they argued, dismissed the relevance of the taste and skills that they had been taught to cultivate, substituting instead an excessive emphasis on intellectual abstractions and political content. Furthermore, they contended, the new art had scared many average Germans away from galleries, theaters, and concert halls. German artists faced starvation, they argued, because German art had been uprooted from its nurturing soil, the people. ${ }^{9} \mathrm{By}$ 1932, the pool of unemployed artists in which such notions could take hold was enormous. ${ }^{10}$

The Kampfbund set forth as one of its paramount goals the need to educate Germans about the intimate connection between cultural decay and national decline. As the inaugural issue of the Kampfbund's newsletter explained, the "political and economic collapse of Germany" after the Great War had been "more than a merely external event." Rather, "it was only the metaphor for an inner lack of belief in the value of Germandom." Similarly, the chaos of Weimar politics merely signified a more fundamental malaise rooted in the "absence of a universally popular state and cultural ideal." The Kampfbund's founders conceived its mission as one of völkisch consciousness-raising. It was to "defend the value of the German essence" in the "midst of present-day cultural decadence" by promoting every "authentic [arteigene] expression of German cultural life." It would "enlighten" the German people about the "connections between race, art, and science." Through lectures and publications, it would promote the work and thought of "important" Germans who had been "silenced" by the forces of decay. ${ }^{11}$

Hitler and other Nazi leaders had scathingly denounced cultural "degeneracy" in speeches and writings since the early 1920s. The fact, then, that the party's systematic effort to instrumentalize cultural anxiety came only in 1928 requires some explanation. Since its refounding in 1925, the party's attempt to attract members from all classes of German society

9. See “Dr. Stang spricht," Deutsche Kultur-Wacht 3 (hereafter cited as DKW), (1932). Many of the $D K W$ issues are not dated.

10. The categories used by the Statistisches Reichsamt make it very difficult to reconstruct unemployment rates for artists. The categories found in the Statistisches Jahrbuch's breakdown of the occupational structure of German society do not correspond to those used to analyze unemployment. This is further complicated by the statistical invisibility nebenberuflicher artists who had entirely different official occupations. For the year 1932, the Reichsamt recorded a quarterly average of 33,118 unemployed in the category "Theater, Music, and Performance of All Types," representing .6 percent of all unemployed. A comparison with occupational census figures yields a rough estimate of 33 percent unemployment among artists.

11. "Die Geisteswende," Mitteilungen des Kampfbundes für Deutsche Kultur (hereafter cited as Mitteilungen), January 1929. 
had met with mixed results. Whereas NSDAP recruitment efforts among the working class had yielded disappointing results, appeals to the middle and upper-middle classes had been more successful. The party leadership resolved, therefore, to concentrate its proselytizing on the various layers of the German bourgeoisie. Germans of the educated and propertied middle class presented a special recruitment challenge. Although not numerous in absolute terms, their adherence would lend respectability to a plebeian movement whose public image derived largely from its lowermiddle-class base and its brown-shirted paramilitary auxiliary. The plebeian stigma had not necessarily had the effect of keeping elites out of the party; to the contrary, several categories of German elites had already demonstrated a higher-than-average proclivity for joining the party. Nonetheless, party leaders sensed that many members of the educated and cultural elite continued to shy away from participation in the movement, despite being quietly or potentially sympathetic. ${ }^{12}$

The founding of the Kampfbund für deutsche Kultur must therefore be viewed as part of the same NSDAP organizational reform of 1928-29 that produced new party auxiliaries for university students, teachers, physicians, and lawyers. ${ }^{13}$ The specific circumstances of the Kampfbund's birth in 1928, however, remain somewhat obscure due to a paucity of documents. Bollmus attributes the main initiative to Alfred Rosenberg, editor of the Völkischer Beobachter, the NSDAP organ, and the party $s$ unofficial chief spokesman on cultural matters. However, Hans Hinkel, founder and leader of the Kampfbund's Berlin chapter, claimed in a postwar statement that Hugo Bruckmann, the Munich right-wing publisher, had been the main force in founding the Kampfbund, and that Rosenberg had merely commandeered it a short time later. ${ }^{14}$ On the surface, the connection with the party appeared to consist mainly of overlapping personnel. Among the first set of thirteen directors, Franz $X$. Schwarz, the Nazi party treasurer, Franz Ritter von Epp, a retired general and Nazi Reichstag delegate, and Rosenberg himself were publicly identified with the Nazi movement. The remainder of the board consisted of prominent non-Nazi members of the German far right wing, such as publisher Julius F. Lehmann, mathematician Philipp Lenard, architect Paul Schultze-Naumburg, and Othmar Spann, a lead-

12. Kater, Nazi Party, 47-48.

13. The question of National Socialist appeals to specific elite groups in German society has generated a substantial literature. Three notable examples are Geoffrey Giles, Students and National Socialism in Germany (Princeton, 1985); Michael H. Kater, Doctors under Hitler (Chapel Hill, 1989); and Konrad H. Jarausch, The Unfree Professions: German Lawyers, Teachers, and Engineers, 1900-1950 (Oxford, 1990).

14. Bollmus, Amt Rosenberg, 30-31; Seventh Army Interrogation Report, SAIC Report 28, "Hans Heinrich Hinkel," 27 May 1945, National Archives, Record Group 238. 
ing exponent of corporatist theory. ${ }^{15}$ These ambiquities pose the question of whether the Kampfbund was at the very outset conceived as an NSDAP front organization, or as an autonomous entity embodying an alliance between National Socialists and other forces of the völkisch Right. In either case, by mid-1929 National Socialist influence in the Kampfbund had become preponderant, even though the connection between the two organizations remained informal.

Given the NSDAP's desire to penetrate the German upper bourgeoisie more effectively, keeping the Kampfbund at arm's length made good strategic sense. Not only would the Kampfbund avoid the plebeian stigma of the NSDAP, it would also exploit a widespread antipathy toward party politics that had infected the German middle and upper-middle classes. ${ }^{16}$ Thus, even as it sought to use art and culture to politicize Germans, the Kampfbund emphasized a pretense to apoliticism. In an effort to avoid possible party-related problems, its published "Operating Principles" stressed the non-party character of the organization. The "fundamental, universal-national" questions to be addressed by the Kampfbund did not "belong to the competence of political parties." 17 This official foreswearing of partisanship was reflected in the Kampfbund's official newsletter, in which references to the Nazi party and Adolf Hitler were conspicuously infrequent. The editors treated the NSDAP as a distinctly separate entity. ${ }^{18}$

Accordingly, the Kampfbund's founders foresaw not a centralized party-style organization, but rather a network of semi-autonomous local cultural associations, bearing the same label and pursuing similar goals. They assumed, or hoped, that the nature of social and associational life, especially in small communities, would enable relatively tiny cadres of activists to make their mark on political discourse and attitudes. Coordinated by a central office, and with the newsletter providing an "intellectual bond,"19 local activists were encouraged to act on their own initiatives in the planning of public lectures and other functions.

15. "Arbeitsgrundsätze und Gliederung des Kampfbundes für Deutsche Kultur," Mitteilungen, January 1929.

16. On apoliticism as a phenomenon of the Weimar right wing see Kurt Sontheimer, Antidemokratisches Denken in der Weimarer Republik: Die politischen Ideen des deutschen Nationalismus zwischen 1918 und 1933 (Munich, 1962), and Armin Mohler, Die konservative Revolution in Deutschland 1918-1932 (Stuttgart, 1950). On grass-roots apoliticism among the German middle classes see Koshar, Social Life.

17. "Arbeitsgrundsätze," as in note 15.

18. In the spring of 1930, when Diemer Willroda, the leader of the NSDAP's "Group Visual Artists" in Dresden, published a piece on "Art, Culture, and Nation" in the newsletter, the author was clearly identified as a guest contributor. "Kunst, Kultur und Nation," Mitteilungen, April-June, 1930.

19. "Arbeitsgrundsätze," as in note 15. 
Members were also especially encouraged to use word-of-mouth to "personally inform all acquaintances about the idea of the Kampfbund." Envisaging a kind of Nazi salon culture, the Kampfbund leadership hoped that "small groups of adherents" would gather for "monthly conversation evenings" to discuss relevant issues and to "deepen personal familiarity." 20

Although the Kamptbund had announced its existence to the world in May 1928, its real work first began in early 1929. Operating out of a small office in Munich, the organization initiated publication of a newsletter, the Mitteilungen, in January 1929. The anonymous editors implored adherents to purchase "as many copies as possible" at ten Pfennige each, and to distribute them to "ideological comrades" (Gesinnungsgenossen) and to "honest persons who still stand outside."21 Each issue contained one or two feature articles dealing in some depth with issues of culture and ideology. Several shorter pieces documented artistic and cultural developments around Germany from the Kampfbund's ideological perspective, often focusing on prominent exponents of modernism and socially critical art, such as Max Reinhardt. These articles were supplemented by previews or summaries of Kampfbund-sponsored functions, and status reports on the growth and activities of various chapters around Germany.

In February 1929 the Kampfbund initiated its series of public lectures. These functions, which were relatively inexpensive and easy to organize, became the most common form of Kampfbund-sponsored activity. Othmar Spann, a member of the Kampfbund Board of Directors, presented the inaugural lecture. An economist best known for his espousal of the organic, corporatist state, Spann had already won substantial popularity among Weimar conservatives. His lecture, entitled "The Cultural Crisis of the Present," called for the elimination of liberalism and democracy, and their replacement by a system of authoritarian leadership supported by popular will. The lecture was a success inasmuch as it attracted a large audience to the main auditorium at the University of Munich and stimulated attention in the press. ${ }^{22} \mathrm{~A}$ short time later, musicologist Alfred Heuss lectured at the university in Munich under Kampfbund auspices. Highly regarded for his research on Händel and Bach, Heuss was the editor of the prestigious Zeitschrift für Musik. Heuss's Kampfbund lecture dealt with "The Crisis of German Music," bemoaning the "formal materialism" that had come to domi-

20. "An die Arbeit," Mitteilungen, May 1929.

21. "Aufforderung," Mitteilungen, January 1929.

22. "Die Kulturkrise der Gegenwart," Mitteilungen, March 1939. In the speech, Spann also made a point of praising the Kampfbund's "non-partisanship" (Überparteilichkeit). 
nate German music at the expense of "metaphysical deepening." 23

After these appearances, neither Spann nor Heuss figured prominently in Kampfbund programming. The spotlight shifted in large part to Rosenberg himself, signaling a shift toward a more pronounced National Socialist dominance of the organization. In April 1929, Rosenberg placed himself on the program for the first time. His lecture was an attack on the trend toward greater sensuality in art, which he saw as one arm in a pincers movement closing in on German culture. Rosenberg ominously described how African primitivism crept into central Europe from the south, promoted by "niggerized Americanism" and French "power politics." Meanwhile, the second pincer, formed by "Mongolian waves of bolshevism," besieged Germany from the east, threatening the "extermination of all German cultural values." Unless stopped, these forces would transform Germany into a formless "swamp culture" (Sumpfkultur). ${ }^{24}$ These dire portents reflected the völkisch right wing's preoccupation with the impulsiveness and sensuality of trends like jazz, and with the role played by Germany's internal and external enemies in the popularization of such movements. Kampfbund propaganda would seize on this theme repeatedly. A golden opportunity to emphasize the conspiratorial nature of the threat presented itself in the spring of 1930, when Paul Robeson (a black) was scheduled to perform in Berlin under the auspices of Max Reinhardt (a Jew). ${ }^{25}$

If Kampfbund adherents could take solace from the the scarcity of blacks in German society, elemental fears of emancipated women could not be so easily repressed. In the autumn of 1929, the Kampfbund launched its first of many attacks on female emancipation. It took the form of a newsletter article titled "Dollarism and Feminism," by one E. Klein-Wintermann of Leipzig. The article combined its indictment of emancipation with an attack on another favorite target, the mammonist culture of modern capitalism. The growing materialism and lasciviousness of contemporary society, the author reasoned, stemmed from the unleashing of feminine instincts hitherto kept under control by civilized people. These included a lust for pleasure, the "gratification of all

23. Donald W. Ellis, "Music in the Third Reich: National Socialist Aesthetic Theory as Governmental Policy" (Ph.D. diss., University of Kansas, 1970), 33-35.

24. "An unsere Mitglieder und Freunde," Mitteilungen, May 1929.

25. "Wider die Negerkultur-für deutsches Volkstum," Mitteilungen, April-June 1930. On an earlier Kampfbund attack on Reinhardt see "Der Fall Reinhardt," Mitteilungen, April 1929. On German prejudices toward blacks and "coloreds" during the Weimar era see Reiner Pommerin, "Sterilisierung der Rheinlandbastarde": Das Schicksal einer farbigen deutschen Minderheit 1918-1937 (Düsseldorf, 1979); Gisela Lebzelter, "Die 'Schwarze Schmach': Vorurteile-Propaganda-Mythos," Geschichte und Gesellschaft 11 (1985): 37-58; and Sally Marks, "Black Watch on the Rhine: A Study in Propaganda, Prejudice, and Prurience," European Studies Review 13 (1983): 297-334. 
imaginable vanities," and "indulgence of every possible sensual and sensory titillation up to the most refined sadism." Klein-Wintermann saw the descent into an "animalistic life of instinct" as "the quintessence of a specifically feminine-determined civilization process." As the article's title suggested, this particular form of degeneration was especially acute in the United States. Echoing a widely accepted stereotype of America ${ }^{26}$ Klein-Wintermann depicted an uncultured society, a "dollar paradise" obsessed with technology (e.g. "senseless automobile driving") and an unbridled materialism. At the heart of this allegedly degenerate system stood "the American female," whose licentiousness and "unparalleled extravagance" had reduced her male companion (the "Yankee") to a "work and love slave," a "trained poodle," an "industriously rotating dollar generator," whose main purpose in life had become the satiation of his mate's acquisitiveness and lust for physical pleasure. To Klein-Wintermann, therefore, America presented a worstcase scenario for unrestrained capitalism's ability to debase the soul, and to emasculate the male. "Americanization" would inevitably produce the same result in Germany. ${ }^{27}$

While lectures, literary readings, and music recitals accounted for the majority of Kampfbund programs between 1929 and 1931, some local chapters seized the initiative to undertake more ambitious projects. The Bonn chapter organized an "Exhibition of the Good German Book," in December 1929. The Bonn Kampfbund arranged for special displays of nationalistic books to be set up in local bookstores, which could in turn integrate the displays into pre-Christmas promotions. ${ }^{28}$ In early 1930 , the Düsseldorf chapter attempted to persuade the city monuments commission to erect a memorial to Albert Leo Schlageter, the German nationalist martyr who, in 1923, had been executed by French occupation authorities in the Rhineland. ${ }^{29}$ At the same time, the Kampfbund activists lobbied against the erection of a monument to Düsseldorf's most controversial son, the poet Heinrich Heine, a baptized Jew and political dissident. ${ }^{30}$ In April 1930, the same Düsseldorf chapter sponsored an elaborate Bismarck festival in the city's concert hall, with the music provided by the local Association of Retired Military Musicians. ${ }^{31}$

26. In his anti-Americanism, Klein-Wintermann was picking up on a theme developed more fully in A. Halfeld's book America and Americanism (Jena, 1927). Stark, Entrepreneurs of Ideolog $\gamma, 177$.

27. "Dollarismus und Feminismus," Mitteilungen, September-October 1929.

28. "An unsere Mitglieder und Freunde," Mitteilungen, November-December, 1929.

29. On the creation and exploitation of the Schlageter myth, see Jay Baird, To Die for Germany: Heroes in the Nazi Pantheon (Bloomington, 1990), chapter 2.

30. "An unsere Mitglieder und Freunde," Mitteilungen, January-March, 1930.

31. "An unsere Mitglieder und Freunde," Mitteilungen, June-August, 1930. 
Conceived essentially on the model of the Bildungsbürgertum, the Kampfbund did not attract members in numbers comparable to those of mass organizations or political parties. From April 1929 to January 1932, membership climbed from 300 to around $2,100 .{ }^{32}$ During this period the Mitteilungen published the names and, in most cases, occupations of 527 new members (i.e., about 25 percent of all members) who had agreed publicly to acknowledge their connection with the Kampfbund. The Appendix presents a sociographic analysis of this data, from which several significant patterns emerge. The Kampfbund, not surprisingly, overwhelmingly attracted elite segments of the German bourgeoisie. The university milieu produced 17.1 percent of the sample, with professors forming the largest single subgroup, representing 12.5 percent of the entire sample. Academic professionals from fields such as the law, medicine, and education constituted an additional 19 percent of the sample. Artists and intellectuals, including writers, editors, performing artists, visual artists, and architects, made up 15.1 percent of the member sample. Entrepreneurs, including several publishers and manufacturers, together with high-level business managers, such as syndics and executive directors (Geschäftsführer), combined to form 5.9 percent of the sample. A bit higher, at 6.1 percent, was the representation of middle and high-level civil servants. Nobility with ranks higher than von and socialites represented 4.2 percent of the sample, and other elites (parsons, officials of social-cultural associations) represented 4.5 percent of the sample. Taken together, all of these socially elite groups, which accounted for less than 3 percent of the total German adult population, ${ }^{33}$ constituted 71.9 percent of the Kampfbund sample.

Beyond the Besitz und Bildungsbürgertum, the sample reflects the Kampfbund's particular attraction for members of the nobility. Of the sample's twenty-two noblemen and noblewomen with titles above the rank of von, nineteen listed no further occupation. ${ }^{34}$ Among them were three princes (including Wolrad and Friedrich Christian of SchaumburgLippe), one princess, and one archprincess. By late 1929, the Kampfbund could also count among its adherents Walter von Bogen $u$. Schöstedt, the executive director of the German Society of Nobility (Deutsche Adelsgenossenschaft).

Among lower-middle-class members of the sample, merchants (Kaufleute) and small businessmen were the most prominent, constituting 8.2 percent of the total sample. Low-level white-collar employees formed 5.7 percent of the sample, and low-level civil servants an

32. Bollmus, Amt Rosenberg, 29.

33. Kater, Nazi Party, 241.

34. An additional twenty-one held the title of von. 
additional 1.5 percent. Only two of the listed members, a machine builder and a railroad assistant, could be classified as skilled manual workers. Taken together, these petit-bourgeois groups (adding in widows and pensioners) composed only 18.6 percent of the Kampfbund sample. By comparison, these social categories formed the collective backbone of the NSDAP, accounting for well over 50 percent of all card-carrying party members.

Women constituted 15.7 percent of the Kampfbund sample, suggesting a level of female representation in the Kampfbund roughly double that encountered in the NSDAP, which discouraged female membership. ${ }^{35}$ It was, perhaps, precisely the pronounced antifeminism noted earlier that attracted tradition-minded women to the Kampfbund. For thirty-one of the eighty-three women in the sample, no occupation was listed, indicating a strong probability that many fulfilled traditional gender roles as wives and mothers. The sample includes four noblewomen and three socialites. Several women in the sample were listed as representatives of conservative and traditional organizations such as the Richard Wagner Association of German Women (Richard-Wagner-Verband deutscher Frauen), the League of German Girl Scouts (Bund deutscher Pfadfinderinnen), and the Association for German Women's Culture (Verband für Deutsche Frauenkultur). In addition to five women who listed themselves as "widows," there were many who identified themselves as spouses (e.g., Geh. Ratsgattin). Although these characteristics of the female membership further underscore the Kampfbund's traditionalist attraction, one should not overlook the presence of significant numbers of females in the professional, artistic, and intellectual subgroups. ${ }^{36}$ Moreover, several women performed important functions for the organization. Winifried Wagner and Eva Chamberlain gave the Kampfbund their blessing, and allowed their names to be associated with it publicly. Elsa Bruckmann, wife of the conservative publisher Hugo Bruckmann, was a member of the first Board of Directors. Other women were engaged as performers at Kampfbund-sponsored events, particularly in Munich. In November 1929, Countess Edith Salburg read from her writings about "old Austrian reminiscences" at a "social evening" held at the Munich Men's Club. The next month, Irma Strunz-Bargehr, a retired Berlin actress, read excerpts from Hölderlin, Goethe, and Schiller at the Munich Festsaal. In February 1930, singer Emmy Krüger of Bayreuth performed

35. Kater, Nazi Party, 254.

36. For lucid discussions of the phenomenon of right-wing women in the Weimar Republic see Jill Stephenson, The Nazi Organisation of Women (London, 1981), chapter 1; Ute Frevert, Women in German History: From Bourgeois Emancipation to Sexual Liberation, trans. Stuart McKinnon-Evans (New York, 1989), chapter 15; and Renate Bridenthal et al., When Biology Became Destiny: Women in Weimar and Nazi Germany (New York, 1984). 
ballads during an evening of "rich artistic enjoyment." In May 1930, Juga Krannhals-Russel, wife of Paul Krannhals, a leading theorist of the authoritarian "organic state," read from her poems. ${ }^{37}$

Aside from considerations of class and gender, the Kampfbund lists also reflect the geographical distribution of members before 1932, suggesting a pattern of highly localized organizational success. As with most grassroots organizations, much depended on the ability and determination of activists on the scene. Of the sample's 527 names, sixty-seven listed Munich as the city of residence. The other larger chapters were Dresden, with forty-six names in the sample; Bonn/Bad Godesberg, with fortyfour; Düsseldorf, with thirty-two, and Berlin, with thirty. Heidelberg, like Bonn an old university town, was home to twenty-eight of those appearing on the lists, while Jena, site of another university, had thirteen names in the sample. On the other hand, only a single member was listed for Tübingen, the site of a venerable university, while none were listed for the university towns of Marburg and Göttingen. In Bavaria, outside of the cultural center of Munich, the Kampfbund established a significant presence only in Nuremberg (including Erlangen), home to nine members on the lists, and, oddly, the small city of Nördlingen, whose six acknowledged Kampfbund members included the mayor. This pattern of isolated successes held true for northern Germany as well. For example the lists showed no members in Bremen, and only four each in Hanover and Hamburg. Yet the obscure community of Quakenbrück placed four residents on the membership lists, while the nearby cities of Oldenburg and Osnabrück had only one acknowledged member between them.

The lists reveal still another important dimension to the Kampfbund's growth between 1928 and 1931. One finds numerous examples of groupjoining by persons drawn from common social or occupational environments. In early 1930, seven Heidelberg university students joined at around the same time, as did two teachers from Weissenfels. In the spring of 1930, four merchants joined in Düsseldorf, as did two widows in Karlsruhe, two junior lawyers (Referendare) in Oppeln, and two retired civil servants in Pöcking (near Munich). These patterns suggest that word-of-mouth and small-scale, informal organizing among personal acquaintances did assist in the Kampfbund's growth, much as the founders had intended. ${ }^{38}$ At the end of 1929 , the Board of Directors expressed satisfaction that Kampfbund members had hosted numerous "functions in

37. Information from the sections "An unsere Mitglieder und Freunde," Mitteilungen, November-December 1929-June-August 1930.

38. This conclusion supports the findings of Koshar, Social Life, on the social roots of National Socialism in Marburg. There is no record of pre-1933 Kampfbund activity in that university town. 
intimate circles" to supplement the more visible public programs. ${ }^{39}$

On only one occasion prior to 1933 did the Kampfbund enjoy an opportunity to exercise direct political power. When National Socialist Wilhelm Frick became Minister of the Interior and Culture in a rightwing coalition in Thuringia between January 1930 and April 1931, he appointed Hans Severus Ziegler, leader of the Thuringian Kampfbund, to the post of "Culture, Art, and Theater Specialist." Ziegler used his position to coordinate a purge of modern art from museums and public buildings under his jurisdiction. Noting the need to protect "moral forces" against "alien racial influences" and the "glorification of Negroism," Frick proclaimed restrictions on performances of "jazz band and percussion music, Negro dances, [and] Negro songs." The Kampfbund newsletter, while carefully avoiding mention of Frick's connection with the NSDAP, warmly praised the measures in Thuringia, noting that "for the first time since 1918, something official is being undertaken against racial and spiritual decomposition." ${ }^{40}$

Frick and Ziegler also brought in Paul Schultze-Naumburg to head the State Academy of Art in Weimar. An original member of the Kampfbund's Board of Directors, Schultze-Naumburg had gradually emerged as the Kampfbund's leading public spokesman after Rosenberg. SchultzeNaumburg is known primarily for his notorious book Kunst und Rasse (Art and Race), published in 1928, in which he argued that the images depicted in abstract or expressionist painting were accurate manifestations of the artists' own state of racial decay. The patent absurdity of this theory should not be permitted to obscure the fact that SchultzeNaumburg had once been counted among Germany's most respected architects. ${ }^{41}$ As a proponent of a kind of progressive historicism in the latter years of the German Empire and the early years of the Weimar Republic, Schultze-Naumburg had sought to synthesize the geometric simplicity of the emerging modern style with essential characteristics of traditional German home design. But the audacity and quick pace of architectural experimentation in the 1920s transformed SchultzeNaumburg into one of the leading critics of modern architecture. ${ }^{42} \mathrm{~A}$ figure of Schultze-Naumburg's stature undoubtedly helped pave the Kampfbund's way to legitimacy in many circles.

With Kampfbund activists at least temporarily inhabiting positions of

39. "Das erste Jahr," Mitteilungen, November-December 1929.

40. "Wider die Negerkultur," Mitteilungen, as in note 25.

41. For example, Berthold Hinz, Art in the Third Reich (New York, 1979), 25, describes Schultze-Naumburg as "one of the leading cultural ideologists of National Socialism," but makes no mention of his earlier progressive tendencies.

42. Lane, Architecture, 156-60. 
power in Thuringia, the organization chose Weimar, the province's capital, as the site for a three-day youth festival in June 1930. Conspicuous on the list of the twenty-eight participating youth organizations were the National Socialist Student League (NS-Studentenbund), the Hitler Youth, and several other groups connected to the Nazi party. Other participants included the Wandervögel, the League of German Girl Scouts, and the National Association of German Officers (Nationalverband deutscher Offiziere). Determined to "combat all manifestations destructive to race and nation," the assembled youth marched through the streets, participated in "strenuous" sporting events, and heard numerous nationalistic speeches. ${ }^{43}$

If the events in Thuringia had contributed to the merging of the Kampfbund's public identity with that of the NSDAP, developments in the Kampfbund's Berlin chapter erased all remaining distinctions. Hans Hinkel, a professional Nazi activist and propagandist from the earliest days of the movement, founded the Berlin chapter in 1930. In 1932, Hinkel, known for his impetuousness and ambition, struck a deal with Joseph Goebbels, the Gauleiter of Berlin, according to which the Kampfbund would serve as the party's "major bearer of the struggle for German culture" in Berlin. Goebbels ordered all NSDAP members in his Gau who were artists and "culture creators" to join the Kampfbund.$^{44}$ It was, however, still possible to be a Kampfbund member without joining the party; the Kampfbund thus retained its function as a back door into the Nazi movement for reluctant Germans. As an NSDAP document from September 1932 explained, the Kampfbund "struggles for the promotion of German culture as defined by Adolf Hitler, however it does not restrict its work to members of the Nazi party." The Kampfbund could therefore "appeal to persons active in German cultural life who decline a formal connection with the party." The Kampfbund would "agitate and assemble" culturally active Germans, drawing them into a circle that would, ideally, "prepare them for entry into the Nazi party," or, at least, into an "atmosphere" imbued with the "principles of the National Socialist movement." 45

In 1932 the Berlin Kampfbund also intensified its propaganda and programs aimed specifically at professional artists, seeking to transform the chapter into a shadow professional association (Berufsverband) modelled on other NSDAP professional auxiliaries. ${ }^{46}$ In the politically rarified

43. "Weimar," Mitteilungen, June-August 1930.

44. "NSDAP für Deutsche Kultur," DKW 3 (1932).

45. "Abmachungen zwischen der Abtl. Volksbildung und dem Kampfbund für deutsche Kultur," 24 September 1932, Berlin Document Center (hereafter cited as BDC), Research Files, Binder 211.

46. “Tätigkeit des KfDK-Gruppe Berlin," DKW 3 (1932). 
cultural environment of Berlin, many artists responded. The Berlin musician Günther Thiele described how the Kampfbund had assisted in his conversion to National Socialism:

Before I entered the party, I joined my National Socialist professional group of the Kampfbund für deutsche Kultur. My registration was on 1 October 1932, under number 4624 (Group Music). In the many weekly meetings I heard discussions of the goals of the Bund. Even when the audience contained only thirty to forty listeners . . . the speakers implanted in me the idea of the Bund and the struggle against Jewish art and against many Jewish artists. I then committed myself against everything Jewish. ${ }^{47}$

In addition to raising the Kampfbund's profile to artists such as Thiele, Hinkel's maneuvers in Berlin had several further important consequences. They made Hinkel a prominent party figure on the Berlin cultural scene, positioning him strategically for powerful appointments after the seizure of power; they gave Gauleiter Goebbels a major voice in the affairs of an organization that was nominally under the leadership of his competitor Alfred Rosenberg; they transferred the center of Kampfbund activity from Munich to Berlin; and they significantly increased the size of the Kampfbund's membership. During 1932, total Kampfbund membership for the entire Reich rose from 2,100 to around 6,000. ${ }^{48}$ Although a good portion of this increase must be attributed to the overall growth of the Nazi movement's popularity, one must surmise that the Hinkel-Goebbels arrangement in Berlin played a major role as well.

Under Hinkel's leadership, the Berlin chapter attracted the participation of several prestigious figures from the local cultural scene. In the field of music, among the most active was Professor Doctor h.c. Gustav Havemann. A violinist, Havemann had become concertmaster of the Lübeck orchestra in 1901 at the age of 19. At age 27 he took over the concertmaster's seat in Hamburg, and at age 33, in 1915, he moved on to the same position at the State Opera in Dresden, one of Germany's finest and most prestigious cultural institutions. In 1920, Havemann was appointed Professor of Violin at the Academy of Music in Berlin, arguably the pinnacle of music pedagogy. Like Schultze-Naumburg, Havemann had come of age in an earlier era, and had experienced the shock of the new with the coming of the Republic. Precisely when he turned to the Kampfbund is not known. By the end of 1932 he had joined the directorate of the Music Section of the Kampfbund, had become director

47. Statement by Thiele, 30 April 1936, BDC, Reichskulturkammer collection, file of Günther Thiele.

48. Bollmus, Amt Rosenberg, 29. 
of the newly founded Kampfbund symphony orchestra in Berlin, and had contributed anti-Semitic articles to Kampfbund publications. ${ }^{49}$ Other prominent musical figures active for the Kampfbund were Clemens Krauss, musical director at the Berlin City Opera, who led the opera section of the Kampfbund's Berlin chapter; Professor Max Trapp, a teacher of composition at the Berlin Academy of Music and member of the Prussian Academy of Arts, who served as coordinator for serious music in the Kampfbund's Berlin chapter; and Prof. Dr. h.c. Paul Graener, who served as the Berlin chapter's expert for music education. A member of the Prussian Academy of Arts, Graener had been a conductor at the Royal Academy of Music in London as early as 1896, had directed the Mozarteum in Salzburg from 1910 to 1914, and had directed the prestigious Stern Conservatory in Berlin since 1930. ${ }^{50}$

In 1932, the Berlin chapter initiated publication of the Deutsche KulturWacht. ${ }^{51}$ This illustrated journal, edited by Hinkel, featured articles on diverse aspects of high and popular culture. The very first issue boasted on page one of the Kampfbund-Berlin's commitment to the cause of "our Führer" Adolf Hitler, and to its intimate association with the NSDAP. ${ }^{52}$ The second issue to appear in 1932 contained a declaration of support for Adolf Hitler signed by fifty-four university instructors, forty-five of whom possessed the title of professor. ${ }^{53}$ Many of the signatories were scholars in the fields of ethnography, cultural history, art, music, and literature: Ludwig Mühlhausen of Hamburg was an expert on Celtic philology; Anton Jirku of Breslau specialized in the history of the Jews of antiquity; Eugen Fehrle of Heidelberg was an authority on German folklore and festivals; Karl Endemann of Heidelberg had published authoritative works on the Sotho languages of southern Africa; Karl Bornhausen of Breslau had authored a study of Pascal's ethics; Ewald Banse of Braunschweig was a prolific scholar of the culture and geography of Asia Minor and North Africa; and Karl Matthaei of Tübingen specialized in the history and performance of organ music. ${ }^{54}$

49. For example, "Was ich vom Kampfbund für deutsche Kultur für die Musik erwarte," $D K W$, special issue (1932). For biographical background see Joseph Wulf, Musik im Dritten Reich: Eine Dokumentation (Gütersloh, 1963; Frankfurt, 1983), 20.

50. For biographical data see Wulf, Musik, 15 (Graener), 204 (Trapp), and Boguslaw Drewniak, Das Theater im NS-Staat: Szenarium deutscher Zeitgeschichte (Düsseldorf, 1983), 399 (Krauss). For their offices in the Kampfbund, see DKW 3 (1932): 18-19.

51. The Kampfbund Reich leadership had been planning to issue its own publication, but decided not to after the Gruppe Berlin seized the initiative to publish its own journal. "Die 'Kultur-Wacht'-Reichsorgan des KfDK," DKW 3 (1932).

52. "Wir gehen in Front," $D K W 1$ (1932).

53. "Deutsche Hochschullehrer bekennen sich für den Führer der nationalsozialistischen Bewegung," DKW 2 (1932).

54. Biographical data in Kürschners Deutscher Gelehrten-Kalender (Berlin, 1928/29). Mühl- 
Kampfbund propaganda, as transmitted through the Kultur-Wacht, points up two important characteristics of the cultural agenda of the National Socialist movement on the eve of its seizure of power, both of which are important for understanding the evolution of state cultural policy after 1933. First, the selection of articles represented a mix of crude racial theory with more mainstream, conservative perspectives on culture. Racist treatises, exposés on Jewish-Marxist influence in the arts, and demands for the elimination of foreigners from German cultural life appeared side by side with feature articles on figures such as Schiller. This hybrid of tradition and radicalism would remain a hallmark of Nazi cultural policy.

A second area of emphasis in the Kultur-Wacht addressed the supposed ravages of capitalism on the material welfare of German artists. The problem in the arts was simply not one of so-called degeneracy, but also one of misdirected financing, poor central planning, and disparities between supply and demand for the services of artists. The magazine provided a forum for ideas about how such problems could be addressed through fundamental economic and structural reform of the arts. For example, many articles sketched out ideas for rationalization of the German theater economy, emphasizing the theme of deliberalization, which usually entailed a combination of professionalization measures, work-creation programs, and audience mass-subscription arrangements. ${ }^{55}$ In the field of music, the Kampfbund called for greater official regulation of the progressive "mechanization" of music through radio, film, and records, and for replacing the existing fractious, increasingly impotent labor unions and professional associations with a corporatist "unified representation of the music estate" that would look out for musicians' economic interests and social concerns more effectively. ${ }^{56}$

In addition to initiating publication of the Kultur-Wacht, the Kampfbund expanded its lecture programming significantly in 1932. A high percentage of the public lectures sponsored by the Kampfbund featured bona fide academics speaking on seemingly apolitical topics, such as "Goethe and

hausen's edited edition of Die Vier Zweige des Mabinogi (Pedeir ceinc $y$ Mabinogi), originally published in 1925, has been recently republished (Tübingen, 1988). Other notable publications by these scholars are as follows: Anton Jirku, Juden Ägyptens in ptolemäischer und römisher Zeit (Vienna, 1924); Eugen Fehrle, Deutsche Feste und Volksbräuche (Leipzig, 1927); Karl Endemann, ed., Wörterbuch der Sotho-Sprache (Hamburg, 1911); Karl Bornhausen, Die Ethik Pascals (Giessen, 1907); Ewald Banse, Die Türkei: Eine Moderne Geographie (Braunschweig, 1919); Karl Matthaei, Ausgewählte Orgelwerke, 5 vols. (Kassel, 1928-36).

$\rightarrow$ Alan E. Steinweis, "The Economic, Social, and Professional Dimensions of Nazi Cultural Policy: The Case of the Reich Theater Chamber," German Studies Review 13 (October 1990): 441-59.

56. "Allgemeine Richtlinien des "Kampfbundes für deutsche Kultur," im Hinblick auf seine musikalischen Aufgaben," DKW 2 (1932). 
Nature," and "Heroism and Human Greatness." 57 German Bestelmeyer, the President of the Academy of Visual Arts in Munich, and also a professor of architecture at the prestigious Technical University in the Bavarian capital, ${ }^{58}$ delivered an address on "Objectivity in Old and New Architecture." Other Kampfbund-sponsored lectures tended to emphasize themes closer to the core of Nazi ideology. Paul Schultze-Naumburg continued to be a popular attraction.

Aside from overt propaganda, the Kampfbund sponsored musical and theatrical performances with increasing frequency in 1932. Kampfbund concerts emphasized the music of great German composers, such as Händel, Bach, and Mozart, and also provided exposure to the works of contemporary composers, exponents of traditionalism such as Paul Graener, Max Trapp, and Hans Bullerian, whose compositions had supposedly been suppressed by the dominant Jewish cabal to bolshevize culture. In the realm of theater, 1932 saw the Kampfbund initiate a theater subscription plan in Munich. The plan was designed to enable the Kampfbund to sponsor its own productions, which would play before full houses of subscribers who had purchased tickets at substantial discounts. This was not an original plan; the efficacy of the subscription arrangement had already been demonstrated by the Volksbühne and similar theater organizations of the Weimar era. ${ }^{59}$ The Kampfbund's mediocre productions of obscure pieces, however, were poorly attended, lost a good deal of money, and were halted after only a few months. Yet the failed experiment did not undermine the National Socialists' faith in the feasibility and political utility of a mass theater subscription scheme, which the Kraft durch Freude organization implemented with immense success during the Nazi regime. ${ }^{60}$

When the Nazi party came to power in 1933, it appeared that the Kampfbund might acquire a dominant role in German cultural life. Nazi officials appointed Kampfbund activists to pivotal positions in cultural administrations at the state and Reich levels. The leader of the Berlin chapter, the Nazi "Old Fighter" Hans Hinkel, was appointed by Hermann Göring to head the Prussian Theater Commission, which, in the spring of 1933, supervised the mass dismissals of ideologically unacceptable theater personnel in Germany's largest state. ${ }^{61}$ Kampfbund activists

57. DKW 4 (1932): 13-14.

58. Biographical data in Kürschners Deutscher Gelehrten-Kalender (Berlin, 1928/29).

59. For an explanation see Guttsman, Workers' Culture, 208.

60. On the success of KdF entertainment programs see Otto Marrenbach, ed., Fundamente des Sieges: Die Gesamtarbeit der Deutschen Arbeitsfront von 1933 bis 1940 (Berlin, 1940), 334-35.

61. Comité des Délégations Juives, Das Schwarzbuch: Tatsachen und Dokumente. Die Lage der Juden in Deutschland 1933 (Paris, 1934), 423. 
were instrumental in the political "coordination" of professional associations and labor unions in the cultural sector; Gustav Havemann, for example, seized control of Germany's largest musicians' union, the German Musician's Association (Deutscher Musiker Verband). ${ }^{62}$ Throughout Germany, artists rushed to join the Kampfbund. Between January and October, membership rose from 6,000 to $38,000 .{ }^{63}$ Most of the new members joined for opportunistic reasons, figuring that membership would increase job security or improve future prospects, although quite a few probably felt genuinely grateful for the opportunity to join a movement with which they had quietly sympathized in the past.

The rapid growth of the Kampfbund in 1933, both in size and in influence, proved deceptive. The Kampfbund had served as a useful tool during the rise to power and the phase of political "coordination." By the beginning of 1934, however, the new Reich Ministry of Propaganda, together with the ministry-supervised Reich Chamber of Culture (Reichskulturkammer), both under the leadership of Joseph Goebbels, had outmaneuvered Rosenberg in the quest to institutionalize Nazi control of the arts. As the compulsory professional organization for culture, the Chamber of Culture embodied many of the very corporatist reform concepts that the Kampfbund had advocated. Ironically, compulsory membership for artists in the Chamber of Culture undermined the Kampfbund's base of support. Artists no longer perceived an urgent need to join the Kampfound, as they had during the confused months of 1933. The decline of the Kampfbund also resulted from Hitler's lack of faith in Rosenberg's capacity to administer a large organization, as well as the Führer's confidence in the ability of Goebbels to reconcile the German culture establishment to Nazi rule. The Kampfbund suffered a severe diminution in influence and status, and from 1934 on, under a new name, the National Socialist Culture Community (Nationalsozialistische Kulturgemeinde) exercised only minor influence in German cultural affairs. Removed from the center of power, Rosenberg's new organization quickly emerged as a hard-line critic of Goebbels's Chamber of Culture, accusing him of coddling modernists and of moving too slowly on the purge of Jews from German artistic life. ${ }^{64}$

Despite its rapid decline, the Kampfbund had left an important legacy. It had helped set much of the cultural agenda for the Third Reich, aggressively promoting corporatism, anti-Semitism, and a hybrid of

62. Documents in BDC, Reichskulturkammer collection, file of Gustav Havemann, and Bundesarchiv Koblenz, Reichskulturkammer-Zentrale (R56I), file 66.

63. Bollmus, Amt Rosenberg, 29.

64. See Volker Dahm, "Die Reichskulturkammer als Instrument kulturpolitischer Steuerung und sozialer Reglementierung," Vierteljahrshefte für Zeitgeschichte 34 (January 1986): 53-84. 
artistic conservatism and "Blood and Soil" radicalism. It had also served as a training ground for many activists who, after 1933, migrated to key positions in the Propaganda Ministry or in the Chamber of Culture. In 1940, Hans Hinkel, who had come to occupy several influential positions in the Propaganda Ministry and the Chamber of Culture, recalled that many "old activists" from the Kampfbund were "still around in this sector." 65 In addition to Hinkel, notable Kampfbund veterans wielding power in the Chamber of Culture included the writer Hanns Johst, who served as President of the Reich Literature Chamber from 1935 to 1945, Otto Laubinger, who led the Reich Theater Chamber from 1933 until his death in 1935, and Heinz Ihlert, who ran the day-to-day operation of the Reich Music Chamber in his capacity as Executive Director.

How significant a role had the Kampfbund played in helping the Nazi movement to power? Until 1932, antirepublican Germans energized by artistic and cultural antimodernism saw the Kampfbund as a means for engaging in the struggle against "decay" while avoiding the descent into party politics. Initially reluctant to sign on with the Nazis, respectable citizens, some of them prominent, lent their names (if not their active participation) to the Kampfbund. In doing so, they avoided direct identification with the Hitler party for a time, but nevertheless conferred respectability on an artistic and cultural worldview consistent with that of the NSDAP. When the Kampfbund began openly and explicitly to boast of its support for Hitler in 1932, it had already secured its image as a reputable organization with numerous socially and artistically prominent members.

Between 1929 and Hitler's appointment to the chancellorship on 30 January 1933, elite support for the Nazi movement grew in almost every measurable respect, be it in terms of party membership, electoral support, or affiliation with professional front organizations. ${ }^{66}$ Several factors converged to produce this shift in favor of National Socialism: intensifying fears of communism, frustration with the messy politics of the Weimar "system," and perceived economic self-interest. The case of the Kampfbund suggests that the National Socialist movement's skill at exploiting the widespread cultural anxiety of the Weimar era was a further significant factor in the formation of the Nazi upper-middle-class constituency.

65. Hinkel to Johst, 20 February 1940, BDC, Reichskulturkammer collection, file of Hans Friedrich Blunck.

66. Childers, Nazi Voter, 243; Kater, Nazi Party, 62; Falter, Hitlers Wähler, 277-85; Giles, Students, 62-100; Jarausch, Unfree Professions, 92-107; Mühlberger, Hitler's Followers, 206. Also see the essays in two excellent anthologies: Thomas Childers, ed., The Formation of the Nazi Constituency 1919-1933 (London, 1986); and Peter D. Stachura, ed., The Nazi Machtergreifung (London 1983). 
APPENDIX

Occupation/Social Background of Self-Acknowledged Kampfbund Joiners, 1928-1931

\begin{tabular}{|c|c|c|c|}
\hline & $N$ & Female & $\begin{array}{c}\text { PERCENT OF } \\
\text { TOTAL }\end{array}$ \\
\hline \multicolumn{4}{|l|}{ University milieu } \\
\hline Professors & 66 & 2 & 12.5 \\
\hline Instructors & 2 & 0 & 0.4 \\
\hline Students & 22 & 4 & 4.2 \\
\hline SUBTOTAL & 90 & 6 & 17.1 \\
\hline Entrepreneurs \& upper management & 31 & 0 & 5.9 \\
\hline High and middle civil servants & 32 & 0 & 6.1 \\
\hline SUBTOTAL & 63 & 0 & 12.0 \\
\hline \multicolumn{4}{|l|}{ Professionals } \\
\hline Medicine & 29 & 2 & 5.5 \\
\hline Law & 14 & 0 & 2.7 \\
\hline Education & 38 & 8 & 7.2 \\
\hline Engineers & 12 & 0 & 2.3 \\
\hline Other & 7 & 0 & 1.3 \\
\hline SUBTOTAL & 100 & 10 & 19.0 \\
\hline \multicolumn{4}{|l|}{ Artists-intellectuals } \\
\hline Writers, editors, journalists & 27 & 6 & 5.1 \\
\hline Artists & 48 & 7 & 9.1 \\
\hline Architects & 5 & 0 & 0.9 \\
\hline SubTOTAL & 80 & 13 & 15.1 \\
\hline Nobility (above von) & 19 & 4 & 3.6 \\
\hline Socialites & 3 & 3 & 0.6 \\
\hline SUBTOTAL & 22 & 7 & 4.2 \\
\hline \multicolumn{4}{|l|}{ Other } \\
\hline Parsons & 6 & 0 & 1.1 \\
\hline $\begin{array}{l}\text { Officials of social-cultural } \\
\text { associations }\end{array}$ & 18 & 4 & 3.4 \\
\hline Subtotal & 24 & 4 & 4.5 \\
\hline Elite Subtotal & 379 & 40 & 71.9 \\
\hline
\end{tabular}




$N \quad$ Female $\quad \begin{gathered}\text { Percent of } \\ \text { Total }\end{gathered}$

Lower-middle class

Low civil servants

White-collar employees

Merchants/small business

Skilled workers/craftsmen

Widows $E$ pensioners

SubTOTAL

No occupation/social position listed

TOTAL

Source: Lists of new members published in the Mitteilungen des Kampfbundes für Deutsche Kultur, January 1929-July/December 1931.

Note: The Mitteilungen listed new individual members who agreed to have their names published. Since the estimated total membership of the Kampfbund was 2,100 as of January 1932, the published names represent about 25 percent of the total membership.

Explanation and examples of categories: Professors: holders of the title Professor; Instructors: holders of the title Privatdozent; Students: those identified explicitly as Student or degree candidate, e.g., stud. theol.; High and Middle Civil Servants: mainly those holding the title Rat, Geheimrat, Regierungsrat; Low Civil Servants: e.g., Regierungsbaumeister, Polizeiwachtmeister, Entrepreneurs: Fabrikant, Fabrikbesitzer, Verleger, etc.; Upper Management: e.g., Syndikus, Geschäftsführer, Verwaltungsdirektor, Postinspektor; White-Collar Employees: e.g., Angestellter, Sekretär, Prokurist, Assistent, Buchhalter; Merchants/Small Business: e.g., Kaufmann, Landwirt, Buchhändler; Skilled Workers and Craftsmen: one Maschinenbauer and one Eisenbahnassistent; Medicine: Arzt, Zahnarzt; Law: Rechtsanwalt, Referendar, Education: Lehrer, Studienrat; Engineers: Dipl. Ingenieur, Chemiker; Other professionals: Apotheker, Wissenschaftler, Archivar, Artists: Musiker, Kunstmaler, etc.; Parsons: counted only if no other function or occupation is given; Officials of social-cultural organizations: representatives of, e.g., Pfadfinder, Deutscher Frauen-Kampfbund, Wandervögel; Nobility: counted only above the level of von, and when no other function or occupation is listed; Socialites: Winifried Wagner, Eva Chamberlain, Daniela Thode; Widows and Pensioners: includes those explicitly listed as such, plus men listing military ranks a.D. without additional indication of occupation. 